\title{
Index of Subject
}

adaptive learning, 26

blended learning, 4, 12, 24, 26, 29, 30, 31, 35, 65, 67, 68, 69, 70, 71, 72, 73, 74, 75, 76

digital book interaktif, 84, 88, 89, 90, 91, 92, 93, 94, 95

Edmodo, 65, 66, 67, 68, 69, 70, 72, 74, 75

fisika dasar I, 13

game, 1, 2, 3, 4, 5, 6, 7, 8, 9, 10, 11, 38, 39, 40, 41, 43, 44, 45, 46, 47, 48, 49

geografi, 3, 65, 66, 67, 69, 97, 98, 99, 100, 101, 102, 103, 104, 105, 106, 107, 108, 109, 110

ilmu pengetahuan sosial, 1

implementasi, 50, 52, 53, 55, 61, 62, 63, 64, 65, 71

Ismaniati, 86, 95, 97

kognitif dan bahasa, 38, 39, 40, 41, 42, 43, 45, 46, 47, 48

Kurikulum 2013, 50, 51, 52, 53, 56, 60, 61, 62, 63, 64

mahasiswa teknologi pendidikan, 84

memory sport, 97, 101, 102, 104, 105, 106, 107, 108, 109, 110

mobile learning, 26, 28, 29, 30, 31, 32, 36, 37, 75

model blended learning, $65,71,72,73,74,75$

multimedia pembelajaran, 2, 29, 30, 31, 38, 40, 41, 43, 46, 47, 48, 77, 78, 79, 82, 83, 84, 85, 86, 88, $89,91,94,96,97,100,102,103,104,105,106,107,108,109,110$

multimedia pembelajaran interaktif, 38, 40, 43, 46, 48, 77, 79, 84, 86, 91, 94

pelaksanaan pembelajaran, 50, 53, 54, 55, 63, 71, 99, 100

pembelajaran teknik komputer dan jaringan, 77

pengembangan media, $7,28,77,85$

R\&D , 5, 13, 38, 43, 65, 71, 77, 79, 89, 105

visual novel game, 1, 4, 5, 6, 7, 8, 9, 10, 11

web enhanced course, 13, 14, 24, 68 


\section{Indeks of Authors}

Ali Muhtadi, 38, 84

Abdul Gafur, 1

Adrie Satrio, 1

Ardian Asyhari, 13, 15, 24, 25

Ence Surahman, 26, 27, 28, 37

Galih Widyatmojo, 38

Herman Dwi Surjono, 26, 29, 37, 86, 96, 103, 110

Mastur, 50

Muhammad Alwan, 65

Oktavia Hardiyantari, 77

Rahma Diani, 13

Sella Mawarni, 84

Yoga Prismanata, 97 


\section{AUTHOR GUIDELINES Jurnal Inovasi Teknologi Pendidikan}

1. Manuscript accepted is written in standard Indonesian language or in standard English.

2. Manuscript must be original and has never been published elsewhere.

3. The length of the manuscript is approximately 10-15 pages (or approximately 6000 words), written in A4 paper format, and referring to the TEMPLATE (availbale online).

4. Manuscript comprises five main headings: Pendahuluan (Introduction); Metode Penelitian (Research Method); Hasil dan Pembahasan (Findings and Discussion); Simpulan dan Saran (Conclusions and Suggestions); Daftar Pustaka (References).

5. The title of the manuscript is written in Indonesian language, must be as brief as possible, and must represent the content of the manuscript (maximum of 14 words).

6. Authors' names are written below the tittle, followed by authors' affiliation and e-mail address.

7. Abstract is written in two languages: Indonesian and English, as a representation of the manuscript. The abstract should not exceed 250 words for each language format (1 page for English and Indonesian abstracts), written narratively in a paragrapgh for each, comprising aims/objectives, method, and findings of the research/article.

8. Keywords: words or phrases which are important, specific, or representative to the article.

9. APA style is used as a reference in citation, references, and writing format.

10. The references of the article are in the form of journals and non-journals which are published in the last 10 years.

11. The manuscript must be in *.doc or *.rtf, and sent to the journal system via online submission by creating account in Open Journal System.

12. All Author(s)' names and identity(es) must be completely embedded in the form filled in by the corresponding author: email; affiliation; and each author's short biography (in the column of 'Bio Statement'). [if the manuscript is written by two or more authors, please click 'Add Author' in the 3rd step of 'ENTER METADATA' in the submission process and then enter each author's data.]

13. Authors' biography (in the column of Bio Statement) is written in the form of narration, including author's full name, place and date of birth, educational qualification/information started from bachelor degree (S1) until the latest educational degree, the affiliation in which the author is currently working, phone number, and email address.

All correspondences, information and decisions for the submitted manuscripts are conducted through email written in the manuscript and/or the emails used for the submission. The status of the manuscript can be checked in the OJS by logging in to the journal. If you have submission queries, please contact teknodik@uny.ac.id 